\title{
Maria Miczyńska-Kowalska
}

The University of Life Sciences in Lublin e-mail: maria.miczynska@up.lublin.pl

\section{THE ECONOMIC CRISIS VS. THE LABOUR MARKET IN POLAND}

\section{KRYZYS EKONOMICZNY A RYNEK PRACY W POLSCE}

DOI: $10.15611 /$ pn.2017.475.16

JEL Classification: J21

Summary: Poland, like other EU countries, was affected by the economic crisis of 2008 which began in the United States. The impact of the crisis in the US on the financial systems of other countries was related to toxic assets secured by real estate which started to have no value because of the collapse of the mortgage market. The situation of Poland and other peripheral EU countries in the era of the Great Recession was relatively good. This was because Polish banks did not invest in toxic assets. Thus, the direct financial channel did not affect the Polish economy. By contract, the financial markets affected it indirectly through fluctuations in asset prices, the availability of money and the change in the intensity of capital flows. Accordingly, the Polish situation regarding employment and unemployment had peculiar characteristics that distinguished it from other EU countries.

Keywords: labour market, economic crisis, unemployment, employment, forms of counteracting unemployment.

Streszczenie: Polska, podobnie jak inne kraje UE, została dotknięta skutkami kryzysu ekonomicznego z 2008 r., który rozpoczął się w Stanach Zjednoczonych. Oddziaływanie kryzysu w USA na systemy finansowe innych państw związane było $\mathrm{z}$ posiadaniem przez podmioty gospodarcze toksycznych aktywów zabezpieczonych nieruchomościami, które przestały przedstawiać wartość na skutek załamania rynku kredytów hipotecznych. Sytuacja Polski i innych państw peryferyjnych Unii Europejskiej w dobie wielkiej recesji była stosunkowo dobra. Polskie banki nie inwestowały bowiem w toksyczne aktywa. Dlatego bezpośredni kanał finansowy nie oddziaływał na gospodarkę polską. Natomiast rynki finansowe przez wahania cen aktywów, dostępność pieniądza oraz zmianę natężenia przepływów kapitałowych oddziaływały na nią w sposób pośredni. W związku z tym sytuacja Polski dotycząca zatrudnienia i bezrobocia miała swoistą specyfikę, która odróżniała ją od innych krajów UE.

Slowa kluczowe: rynek pracy, kryzys gospodarczy, bezrobocie, zatrudnienie, formy przeciwdziałania bezrobociu. 


\section{Introduction}

The issue of work and unemployment is of interest to sociology because work is of great importance for the functioning of societies. In sociology, work is recognised as a process, "as many interconnected relationships of social phenomena related to social groups and communities" [Stępien 2005, p. 175]. Work is a "free, but of course necessary, human activity, flowing from a sense of duty, coupled with difficulty and joy, and intended to create spiritual and material values useful for the society" [Strzeszewski 1994, p. 580]. The work process is supposed to adjust immediate natural and social surroundings to human needs. Work is the most common way to earn a livelihood.

The concept of labour market is closely connected with the concept of work. In economic sociology, sociology's sub-discipline which uses economic terms, the labour market is defined as an area that brings together job-sellers with their job offers (which they offer for sale) with job-buyers, i.e. companies seeking work [Nojszewska 1995, p. 190]. For sociologists, the concept of the labour market constitutes an institution of social life that covers both behaviours and actions of job seekers, as well as behaviours and actions of job providers. The labour market is about specific rules of hiring people, the rules of remuneration, promotion, dismissal as well as obtaining specific rights and benefits in exchange for the work done. The labour market also constitutes certain physical places and organisations where specific activities are carried out. The labour market functions both at the level of the whole society and in the level of regions, industries, businesses, etc. [Domański 1992, p. 114]. On the labour market, labour is allocated through workers negotiating with employers, and the result is an employment contract [Władyka 2007, p. 166].

In today's world, one of the most pressing problems that still has not been fully resolved is the problem of unemployment. Initially, unemployment intensified in the $1930 \mathrm{~s}$, when in many countries it exceeded $25 \%$. The scale of unemployment increased also in the 1980s and 1990s in countries undergoing transformation, including Poland. Another crisis, this time worldwide, took place in 2008, and it has been referred to as the Great Recession. This crisis had various impacts on labour markets and unemployment rates of the EU countries. In economics, unemployment is regarded as an analytical category of the labour market. It is referred to as an "unrealised supply of labour, which is the result of an imbalance between labour supply and labour demand" [Potasińska 2014, p. 8].

Currently, the Polish legislation defines the unemployed as follows: "people unemployed and not performing other paid work, capable and ready to take up employment in full-time mode in given professions, services or other paid jobs; or disabled people, capable and ready to take employment in at least half of the standard working time; people not attending school, with the exception of those attending schools for adults or taking external examinations covering the curriculum of these schools or universities where they study part-time; people registered in the 
correct district labour office according to their place of permanent or temporary residence, seeking employment or other economic activities" Dz.U. No 99 2004]. We distinguish the following types of unemployment: conjunctural (transformational or cyclic), frictional, structural [Kwiatkowski 2002, p. 46]. In Poland, all these types of unemployment have been marked on the labour market.

The aim of this article is to present the situation on the labour market in view of the situation under the influence of the Great Recession, taking Poland as an example. The article presents the causes, the course and the macroeconomic effects of the crisis which began in 2008 in individual EU and OECD countries. It presents the specifics of the labour market in Poland facing the economic crisis and in later years, up to 2015. The study used an analytical and synthetic method as well as a secondary analysis. The article contains definitions of basic concepts related to the topic. It presents the conditions for the emergence of the Great Recession. It contains an analysis and a synthesis regarding the labour market in Poland in the period under review and shows the country's efforts to reduce the level of unemployment as well as the improvement of the Polish labour market's situation by 2015, as indicated by the employment rate in Poland (which is currently only 2.6 percentage points lower than in the EU). The article stresses that the state policy pursued during the economic crisis, as well as in later years, helped to reduce the level of unemployment. It points out that (during the crisis and in later years) the categories of workers that were the most vulnerable to unemployment included young people, especially first job seekers, the elderly aged 60 or more, women, as well as people without profession with a low level of education. In contract, factors that reduced the risk of long unemployment included: higher education, investing in knowledge, active job search, mobility, openness to new forms of employment, including the use of temporary work services, as well as flexible forms of employment.

\section{Great Recession}

The great economic recession began in the United States in mid-2007. It was caused by speculations in the property market, which in turn led to a deep crisis in financial markets. This crisis turned into the biggest global recession since World War II and has been given the name of the Great Recession. The Great Recession consists of two phases. The first one involves problems in the real estate market, the crisis of the financial markets, as well as direct consequences that these events have had on the economy. In contrast, the second phase is connected to the worsening state of the public finances of the United States and the EU countries. The second phase was due to lower tax revenues and expansionary fiscal policies adopted by governments in order to stop the first phase of the crisis. Due to the tightening of fiscal policies and the increasing costs of servicing the public debt, many countries stood on the brink of bankruptcy. Problems of the real estate market gave rise to the economic recession. For example, they led to a decline in the construction sector and its related 
sectors; to a deterioration of public finances. Consequently, these factors led to the economic recession which was highlighted by a decline in employment and GDP. The direct impact of the crisis in the US on financial systems of other countries was related to toxic assets secured by real estate which started to have no value because of the collapse of the mortgage market.

The situation of Poland and other "new" EU member states in the era of the Great Recession was relatively good. This was because Polish banks did not invest in toxic assets. Thus, the direct financial channel did not affect the Polish economy. By contract, the financial markets affected it indirectly through fluctuations in asset prices, the availability of money and the change in the intensity of capital flows. The effect of the Great Recession in Poland was the decline in the value of the index of the Warsaw Stock Exchange by half, which in turn affected balance sheet accounts of financial institutions, as well as the wealth of households. At the beginning of the Great Recession, Poland experienced large exchange rate fluctuations. The deteriorating macroeconomic situation resulted in an increase in unpaid loans. The government's actions in the field of anti-crisis measures were not as strong. These focused mainly on reducing the negative consequences of the crisis on the labour market and changes in tax law, favourable for those conducting business activities. In 2008, the direction of anti-crisis measures was determined by two documents: The Stability and Development Plan of 30November 2008 and the Reliance Package adopted by the Polish National Bank on 14October 2008. In May 2009, the Monetary Policy Council lowered the reserve requirement rate from 3.5\% to 3\%. Like other countries, Poland also applied an expansive monetary policy. Between November 2008 and June 2009, the Monetary Policy Council lowered the reference rate from $6 \%$ to $3.5 \%$. This resulted in a decrease in credit costs. Other anti-crisis measures taken by the Polish government included: introducing lower personal income tax rates in 2009, adopting VAT tax settlement changes favourable for companies, adopting the Act on mitigating the effects of the economic crisis for employees and entrepreneurs in 2009.

It is obvious that individual North American and EU countries differ in the way when and with what intensity the Great Recession affected them to the greatest extent. In 2008-2009, the Baltic states were hit the most. In 2010-2012, in the second phase of the crisis, these countries were in turn the fastest to develop. From among EU countries, Poland deserves attention for

Poland's situation was specific. The country avoided deep recession due to the lack of a collapse in the property market and its banking system's low exposure to loss, as well as due to the lack of a liquidity crisis. Accumulating public investments financed from EU structural funds helped as well. In general, however, it should be emphasised that the crisis had an impact on the financial position of households as the risk of job loss was higher. 


\section{Polish labour market during the Great Recession and in later years}

Labour market adjustment to the changes occurring under the influence of the Great Recession may be related to the following issues: changes in the number of people working, working time, forms of employment, remuneration. The slowdown in economic growth during the Great Recession implies a decline in the demand for labour and other consequences manifested in increasing unemployment. In most countries affected by the crisis, the labour market situation started to deteriorate already in 2008. The unemployment rate, however, continued to grow in 2010-2012, although the European market situation was improving systematically.

When analysing the long-term situation on the Polish labour market, economic expansion was occurring until 1998, 1999-2003 were the years of a crisis, whereas 2004-2008 were the years of an economic growth which implied a reduction in the level of unemployment. In 2008, the unemployment rate reached its lowest level of $9.5 \%$. The first most acute phase of the Great Recession resulted in a sharp increase in the unemployment rate to $12.1 \%$. This increase, however, compared to other European countries, was not very severe and did not reach the level of 2004 (19\%). Years 2009-2012 saw a stabilisation on the labour market, although the unemployment rate was slightly increasing to reach its peak in 2012. In 2013, the unemployment rate started to decrease rapidly, and in 2015 the situation on the labour market returned to the state from before the Great Recession. Figure 1 presents the unemployment rate during the Great Recession and in later years.

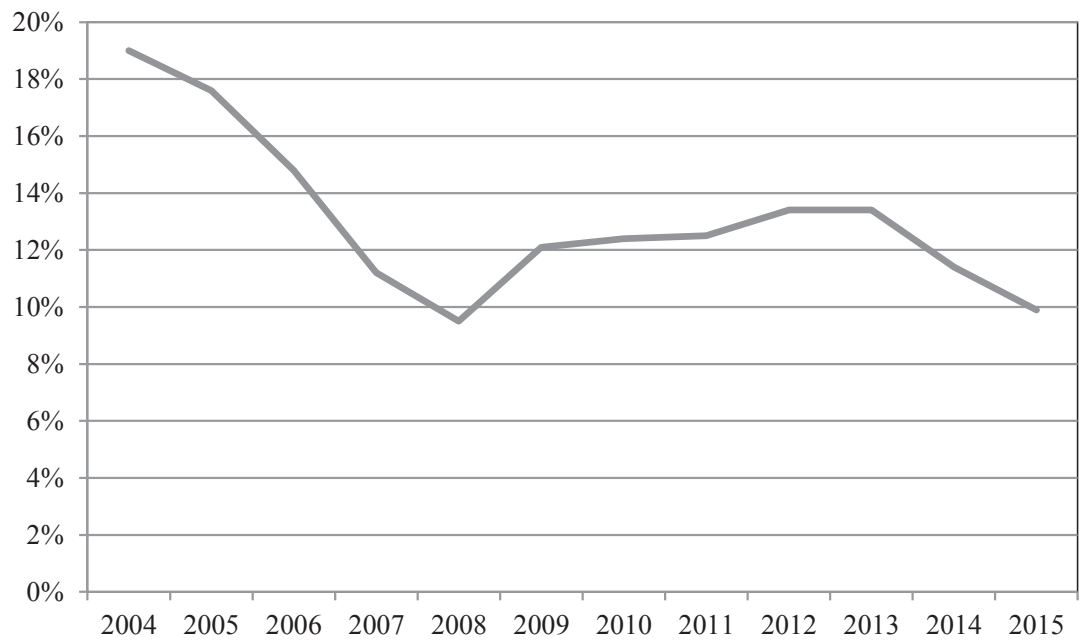

Fig. 1. Unemployment rate in \%

Source: [www.polskawliczbach.pl]. 
The crisis did not cause structural changes in the labour supply in age groups. Only a small impact of the recession is observable in the case of the 55-59 and $60+$ age groups, where the growth trend of the unemployment rate was consistent since 2002. However, their level of unemployment in absolute terms is the lowest. The reason for this is the ageing population, the growth of the economic activity of older people, as well as the lack of a generational change in positions requiring expertise. Figure 2 shows the levels of unemployment by age in Poland during the aforementioned period.

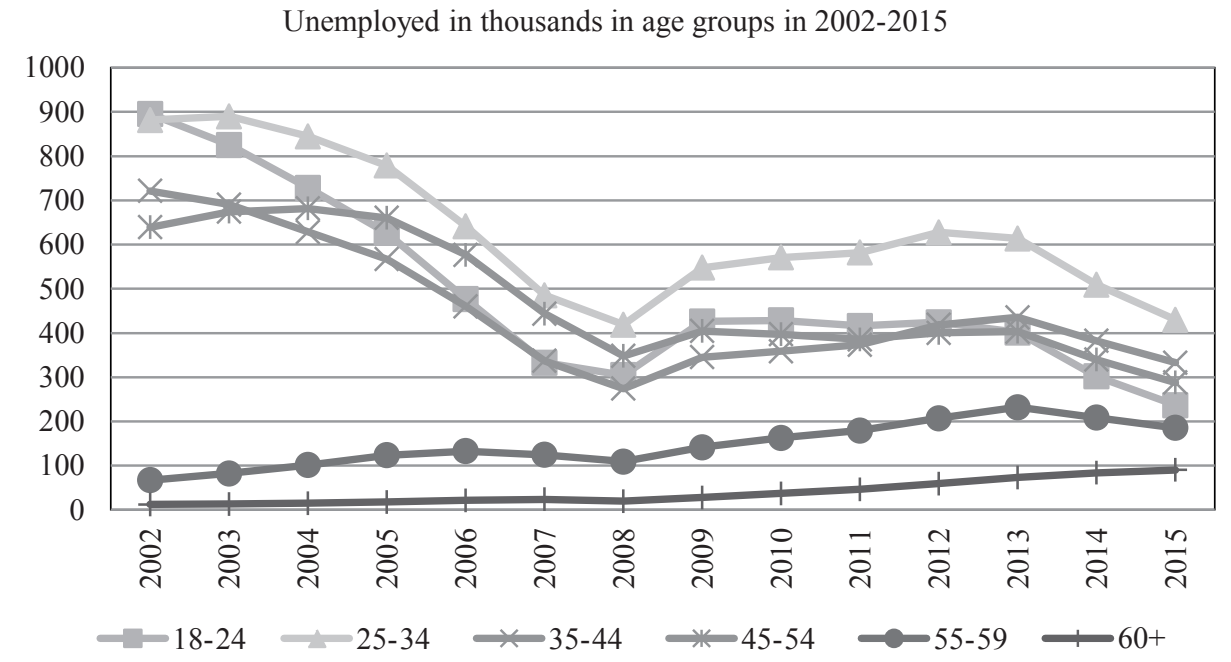

Fig. 2. The unemployment rate in thousands by age between 2002-2015

Source: [Ministerstwo Rodziny, Pracy i Polityki Społecznej].

When analysing the absolute values, the age group covering employees aged 25-34 was mostly affected by unemployment, whereas there were relatively few employees aged 18-24 years on the labour market. This is due to the trend regarding the increased number of university students. Nevertheless, these two age groups were mostly affected by the Great Recession. In the first phase of the crisis, employees in the 35-44 age group were least affected by changes on the labour market, but in their case this trend was reversed in the second phase in 2009-2012. This is a group of employees with relatively high income, and this was the reason for replacing them with younger and cheaper ones. In 2012, the age groups 18-24, 35-44 and 45-54 reached almost the same level of employment. The end of the Great Recession saw a return to the trend of reducing the level of unemployment in these age groups that were providing extensive experience on the labour market, as well as among young people with low qualifications. However, the relatively poor situation of employees aged 25-34 is alarming because it results in a lack of generational replacement in positions requiring 
specialised and managerial skills. Compared to the EU countries, Poland stood out in 2015 in terms of going back to the professional activity rate level from 2008.

Consequences of economic crises unevenly affect individual socio-professional categories of employees. On the one hand, younger employees face the threat of unemployment to a greater extent than older employees (these being effects of fluctuations in the economic cycle) due their shorter experience. On the other hand, older employees are more expensive for employers, and that is why these employees might be dismissed in the first place. Thus, the dynamics of employment of young people is associated with changes in the economic situation, and the same dynamics for older employees depends on structural factors. In the knowledge society, in which knowledge constitutes the primary capital, employees with specific, specialised education are affected by unemployment to a lesser extent than employees without qualifications, even in crises.

When analysing Poland's structure of unemployment by gender, women are traditionally worse off compared to men. This was most evident in the period of the economic growth in 2004-2008. By contract, the Great Recession caused a relative improvement in the situation of women on the labour market, and at the end of the first phase of the crisis in 2009, women had almost equal chances on the labour market. The reason for this is, unfortunately, a negative factor which are lower wages offered to women for doing the same job. Figure 3 shows the levels of unemployment by gender during the aforementioned period.

\section{Unemployment by gender in thousands in 2002-2015}

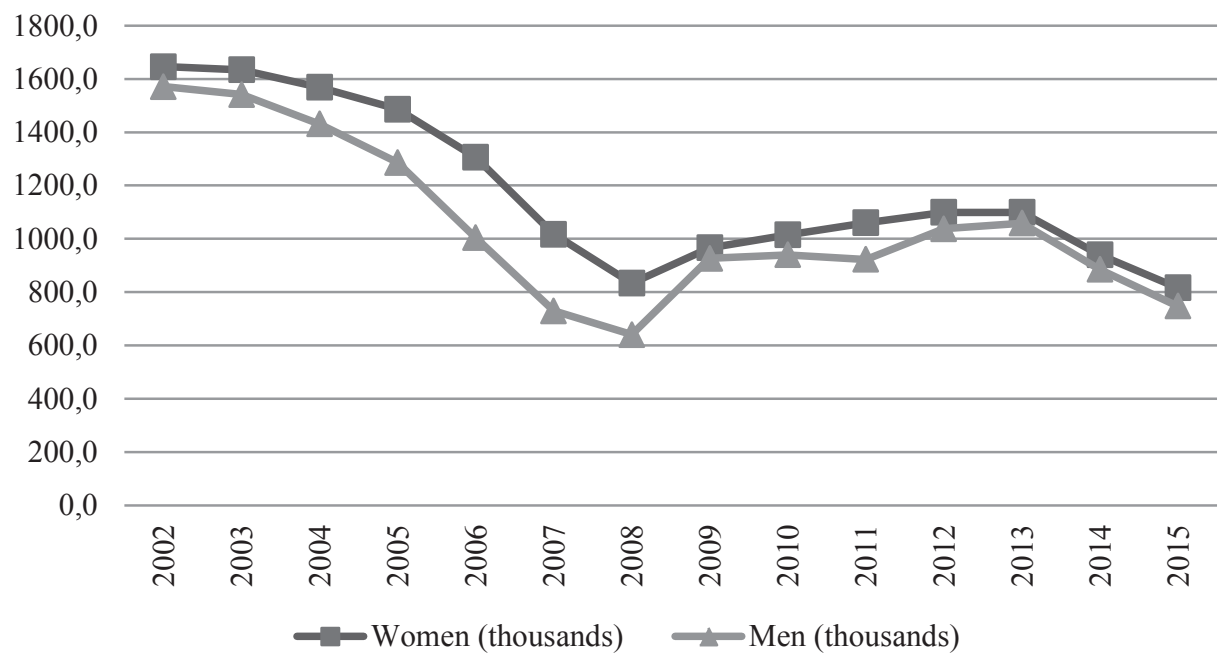

Fig. 3. The unemployment rate by gender between 2002-2015

Source: [Ministerstwo Rodziny, Pracy i Polityki Społecznej]. 
In crisis conditions, the following individuals are exposed to unemployment to a greater extent: employees involved in the sector most dependent on external financing which decreases during the recession; and employees working in the area of manufacturing, wholesale and retail trade as well as construction because the demand for their products and domestic consumption decreases due to an uncertain situation on the labour market. These are also traditional activities which in absolute terms register the highest unemployment. However, the least likely to lose their jobs during recession are those employed in services, public administration, national defence, agriculture, forestry and fishery. These are also the groups with the lowest registered unemployment. Figure 4 shows changes in the number of the unemployed according to the official qualification of activities in Poland.

Registered unemployed in thousands according to the official qualification of activities in Poland
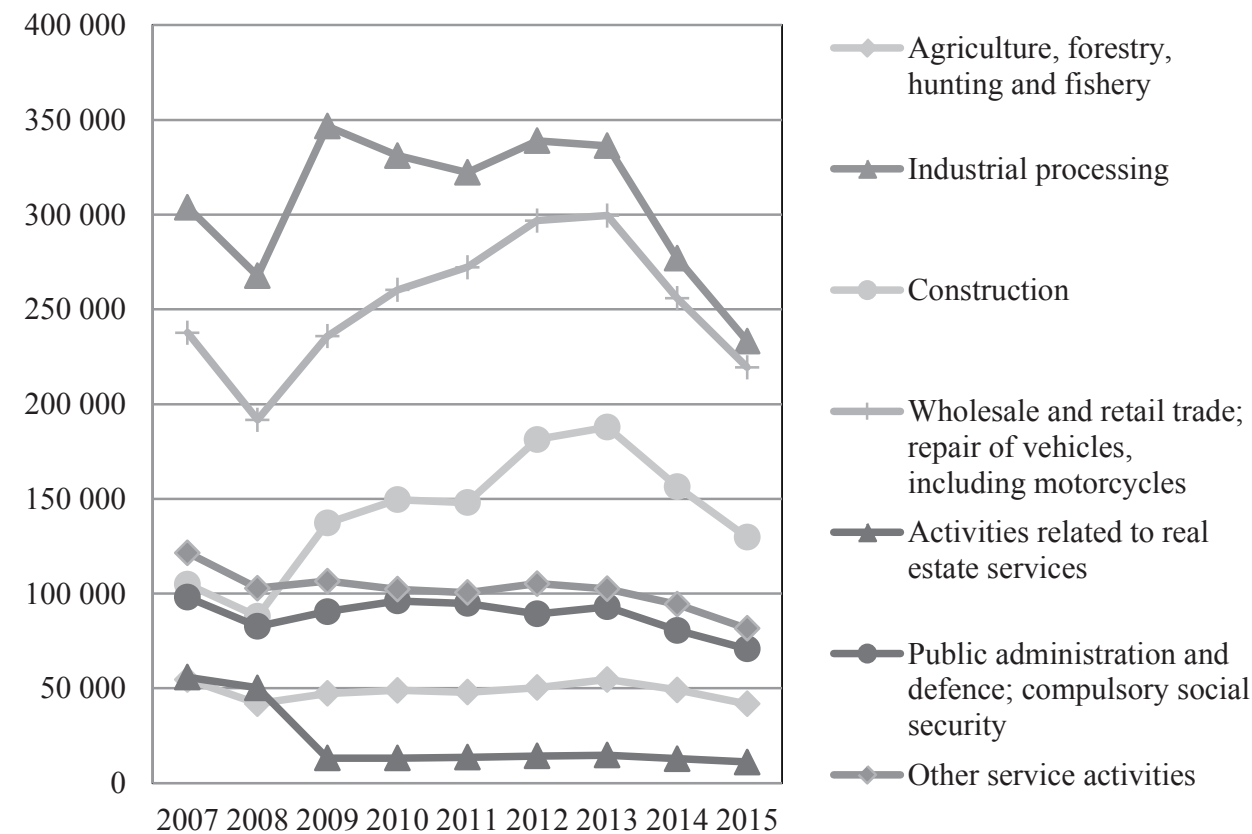

Fig. 4. The unemployed in thousands according to the official qualification of activities in Poland Source: [Załącznik 2...].

In the EU, a process of reducing the employment of people involved in simple physical jobs to increasing the share of high-skilled white-collar workers has been ongoing for years. What is specific about Poland is its relatively large percentage of the population employed in agriculture compared to other EU countries. In Poland, the share of employing qualified workers has not declined. In contrast, the demand 
for white-collar workers did not undergo significant modifications compared to the period before the recession, just as in most EU countries. If, in turn, we are talking about the mismatch of skills of employees, it arises from a mismatch of supply and demand on the labour market. However, the lowest percentage of the unemployed ever since 1989 was recorded in September 2016, and it amounted to 8.3\%. The third sector of the economy, i.e. services, gives a chance to adsorb the unemployed. It would make sense to transfer labour from uncompetitive industries to services, an area in which demand is constantly increasing [Janowska 2005].

When analysing the level of unemployment in terms of education, university graduates and people with upper-secondary education are the least vulnerable to unemployment. The rate of growth in unemployment among those in the first phase of the Great Recession was also the smallest. Figure 5 shows the number of the unemployed according to their formation.

The number of the unemployed in thousands in terms of education in 2007-2015
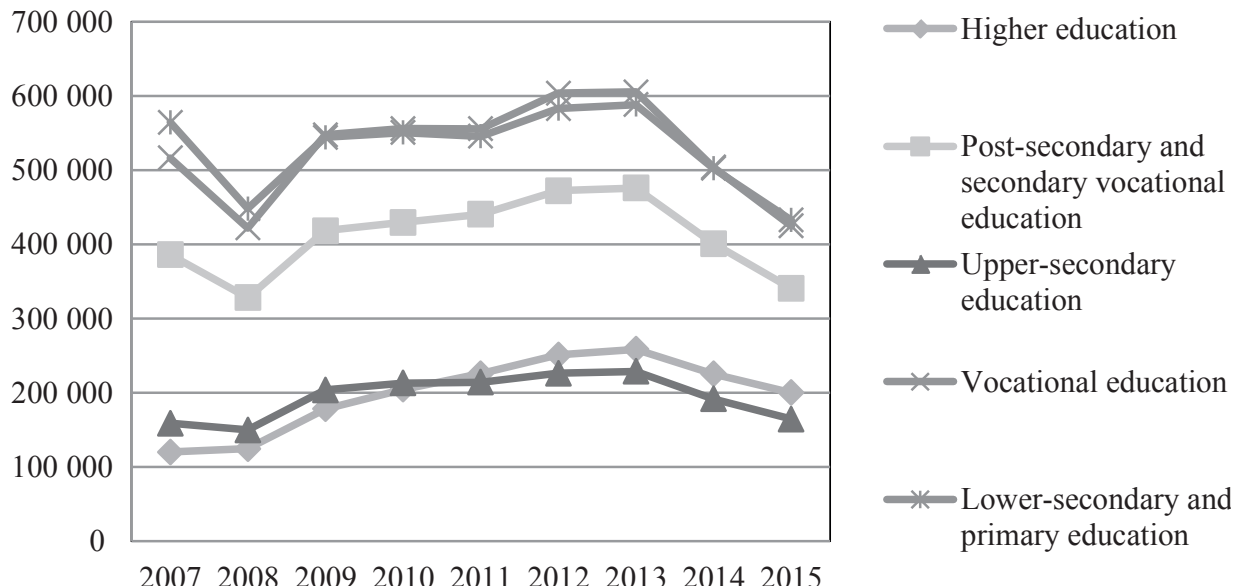

Fig. 5. Number of the unemployed according to their formation

Source: [Załącznik 2...].

The highest number of the unemployed is registered among people with vocational, lower-secondary and below, as well as post-secondary and secondary vocational education. The growth rate of the number of registered unemployed among such people in a situation of recession is also the highest.

The so-called flexible forms of employment have appeared in Europe in recent years. European countries differ in terms of the proportion of employees on the basis of the said form. The impact of the Great Recession on the number of concluded contracts for a specified period was low. In 2012, the lowest percentage of contracts 
of this type concerned Estonia - less than 5\%, and the highest concerned Poland $27 \%$. Statistics show that mostly young people and the elderly work on fixed-term. Part-time work, so popular in European countries as a flexible form of employment mitigating the effects of unemployment, has not found wide application in Poland.

The period of economic growth before the crisis was associated with rising employment and increasing household income, also of the poorest. This situation was not particularly affected by the influence of the Great Recession. During the Great Recession, the relative position of the least-earning people working for an indefinite period improved, and the income inequality of self-employed decreased. The income situation of farmers stabilised. However, it was of diverse nature. The gap between average and top wages decreased as well. The average annual net income per capita is presented in Figure 6.

The average annual net disposable income in PLN per 1 person in a household in 2007-2014

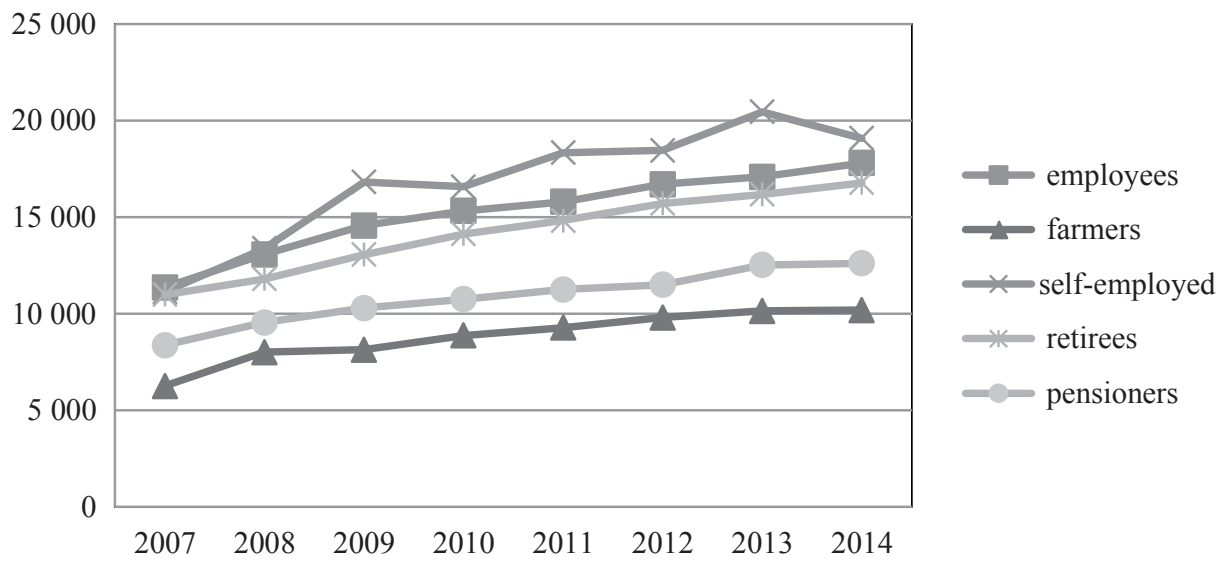

Fig. 6. The average annual net disposable income per capita

Source: [Central Statistical Office 2007-2015].

The Great Recession did not influence the level of income. The upward trend is maintained continuously, but there are still large differences in income. The worst income situation concerns farmers, and self-employed and industrial employees are in the best situation. Figure 7 shows average gross wages.

In relation to remuneration, about $30 \%$ of employers declared that part of the remuneration constituted the so-called flexible component of wages. Employers pay it only when employees reach certain pre-agreed results. Therefore, employers may lower real wages without renegotiating agreements. When a crisis hits, it is difficult for employees to achieve specific results. Labour costs in Poland are close to the European average, while real wages are far below. This makes many Poles decide to emigrate to richer countries. 


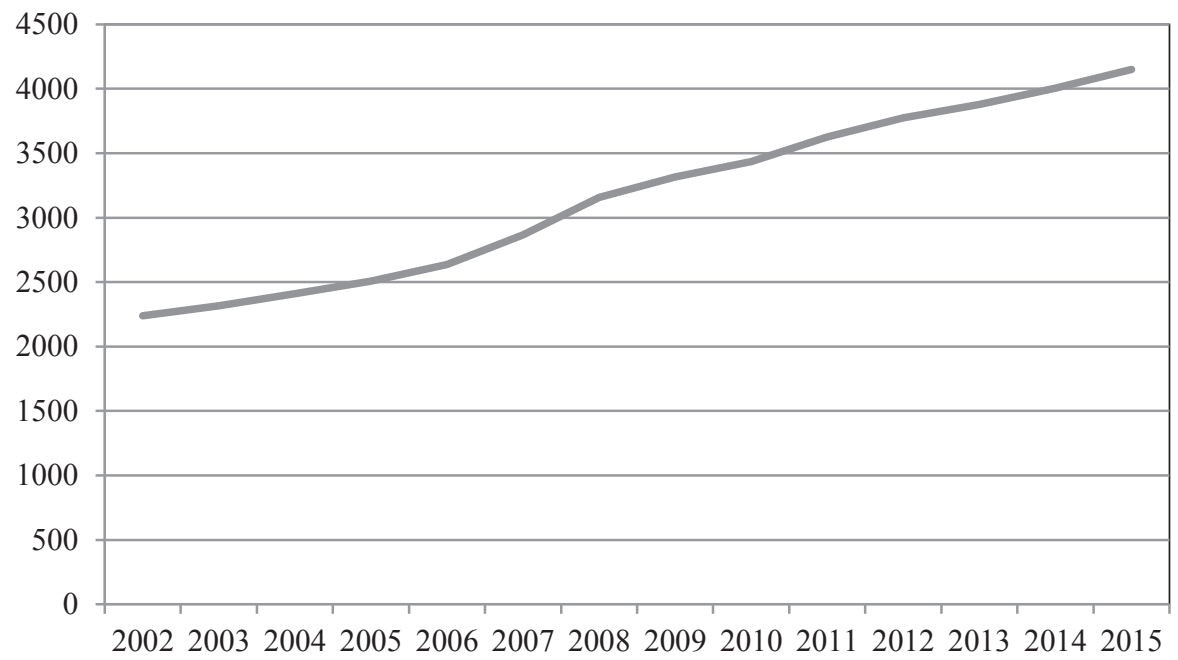

Fig. 7. The average gross salary in PLN

Source: [www.polskawliczbach.pl].

\section{Conclusions}

When concluding the reflections on the contemporary labour market situation in Poland, it should be pointed out that the employment rate in Poland is only 2.6 percentage points lower than in the EU. The labour market situation has improved. However, there is still a lot to do. What is specific about Poland, as well as other countries of the Eastern bloc, is its system transformation and the transition to a market economy. This process was related to the appearance of unemployment (lasting for years at a high level over ten per cent), associated with the restructuring of the economy and a mismatch of labour market needs and skills. The state policy pursued during the economic crisis, as well as in later years, helped to reduce the level of unemployment. The categories of workers that are the most vulnerable to unemployment are young people, especially first job seekers, the elderly aged 60 or more, women, as well as people without profession with a low level of education. The improved situation on the labour market regarding the level of unemployment results in an increase in salaries, and consequently in a lesser interest in economic emigration.

\section{Literature}

Domański H., 1992, Zadowolony niewolnik. Studium o nierównościach między mężczyznami i kobietami w Polsce, PAN, Warszawa.

DzU 2004 nr 99, poz. 1001, art. 2. poz. 211, art. 2. 
Główny Urząd Statystyczny, Dochody $i$ warunki życia ludności Polski (Raport z badania (EU-SILC 2007-2015).

Informacja o rozmiarach i kierunkach emigracji z Polski w latach 2004-2012, 2013, Główny Urząd Statystyczny.

Informacja o sytuacji społeczno-gospodarczej w kraju w 2015, styczeń 2016, GUS, Warszawa.

Janowska I., 2005, Rozwój sektora ustug a rynek pracy w Polsce w świetle doświadczeń krajów wysokorozwiniętych, [in:] Edukacja i przedsiębiorczość a bezrobocie, Roman A. (ed.), Wydawnictwo Wyższej Szkoły Finansów i Zarządzania w Białymstoku, Białystok.

Kwiatkowski E., 2002, Bezrobocie. Podstawy teoretyczne, Wyd. PWN, Warszawa.

Ministerstwo Rodziny, Pracy i Polityki Społecznej, https://www.mpips.gov.pl/analizy-i-raporty/bezrobocie-rejestrowane-w-polsce.

Nojszewska E., 1995, Podstawy ekonomii, WSiP, Warszawa.

Potasińska A., 2014, Bezrobocie z perspektywy socjologicznej, Wydawnictwo Uniwersytetu Kardynała Stefana Wyszyńskiego, Warszawa.

Stępień J., 2005, Socjologia pracy i zawodu, Wydawnictwo Akademii Rolniczej im. Augusta Cieszkowskiego, Poznań.

Strzeszewski Cz., 1994, Katolicka nauka społeczna, Redakcja Wydawnictw KUL, Lublin.

Władyka T. (ed.), 2007, Polityka gospodarcza, Wydawnictwo Oficyna a Walter Kluwer Business, Warszawa.

Załącznik 2 do sprawozdania MPiPS-01 raport Polskiego Ministerstwa Pracy i Polityki Społecznej o rynku pracy, Bezrobotni wedtug rodzaju działalności ostatniego miejsca pracy, poszukujący pracy oraz wolne miejsca pracy i miejsca aktywizacji zawodowej.

Załącznik 3 do sprawozdania MPiPS-01, raport Polskiego Ministerstwa Pracy i Polityki Społecznej o rynku pracy, Bezrobotni oraz wolne miejsca pracy i miejsca aktywizacji zawodowej wedlug zawodów i specjalności.

www.polskatimes.pl/stronaglowna/61184 emigranci 07052009.

www.polskawliczbach.pl. 